\title{
Elizabeth I of England
}

\author{
Elinor Kapp
}

This bs the fint in a short serles of aticles on portralls of chlidren from the point of viow of a child poychictilst.

This is the earliest identifiable portrait of Elizabeth, probably painted in 1546 in the last year of the reign of her father, Henry VIII. Her birth in 1533 had been $a$ great disappointment. Her father, Henry and his hastlily crowned new Queen, Anne Boleyn, desperately wanted a boy to ensure a peaceful succession. Elizabeth was not 3 years old when her mother went to the tower and the block and through all the years of her growing up her fortunes fluctuated wildly and the people around her blew hot and cold for reasons no child could comprehend. Her father declared her a bastard and cut her out of the succession, restoring her to partial favour after the birth of her half-brother, Edward in 1537. She and her half-sister, Mary, grew up together and she was given an intenstve bookdsh education, but she was stlll regarded as lllegitimate and awways suspect because of her mother, tainted by that wild lady's adultery, treason and suspicion of witchcraft. She was in an excellent position to see the faction, the scheming, the deceit that surrounded the ageing and increasingly mentally unstable Henry. She herself was the target of ambitious and treacherous men whose attentions to her more than once led her into great danger and even imprisonment in the tower. She learnt early, and the hard way, to hold her tongue and trust no-one, least of all in matters of love and marriage. She learnt above all to charm men into adoration by flirtation, capriciousness, and unobtainability.

The artist is unknown, but it is a wonderfully skdlled picture both technically and psychologically. The palette is limited to shades of red and gold. The figure glows out in a salmon pink dress against dark browns. She is placed centrally, her head framed by indistinct draperies against the darkest shades, repeated at the lower corners, and in the darkness of her eyes, emphasising the flesh tints of a beautiful young skin. The

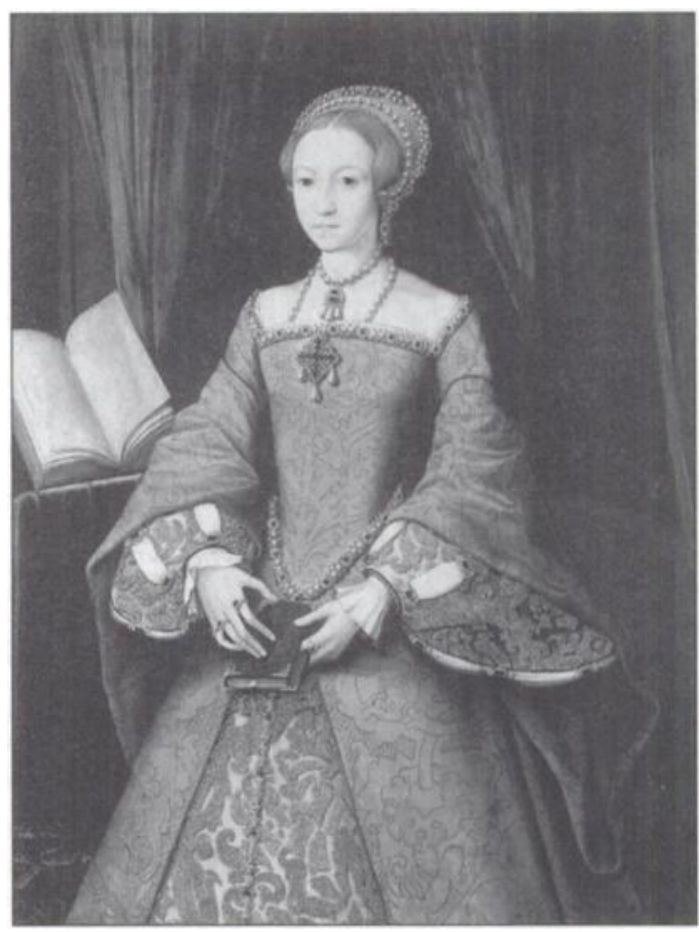

Elizabeth I when Princess (1533-1603). Artist unknown. Copyight Her Majesty Queen Elizabeth II.

triangular shapes of the draperies, sleeves and bodice, all emphasise the head and shoulders, then draw the eye down to the secondary focus in the slim hands marking the place in a book as if she has simply been disturbed at her reading and will return to it. Symbolically this shows learning and wisdom with the open book at the side to further the impression. They probably also suggest plety, as do the pearls, a symbol of Mary, for youth, innocence and purity. The little half hoop head-dress frames her marmalade coloured hair most flatteringly. The ridiculously padded undersleeves show the restraints of her 
position. Almost literally her 'hands are tied' by position and riches. The skirts balloon out into a solid base like that of a legless sexless doll. She can only move slowly and ceremoniously. The contrasts show up the painful vulnerability of her youth and her status. The source of light is uncertain, diffuse, glowing from within. We see her as an attractive young girl, just on the point of blossoming into womanhood. Not ordinarily pretty, with her long face, but with beautiful skin and hands, embellished with several rings and slightly self consciously marking the place in her book. She shows poise, dignity and excellent breeding, as befits the daughter of a king. She is grave, demure and guarded. Her eyes are wide open and candid, but the set of her head on the neck and the folded lips show a wariness that gradually as one studies the picture becomes the most striking thing about it. There is a haunting loneliness about its reluctant but obsessive secrecy. No hint of laughter, of relaxed pleasure, or the delicious trial of innocent flirtation that should be the inheritance of the pubertal girl, but a frozen watchfulness that recalls to me countless victims of deprived or abused childhoods. Perhaps it seems strange to compare a Royal portrait of 400 years ago with children from the psychiatric clinic but I have seen this face so many times in victims of emotional and sexual abuse. Streetwise children old before their time. Proud, stoical, watchful children. on whom the adult world has stamped its indelible mark too soon, children who betray behind their eyes a sort of wistfulness, as if some part of them knows what they have lost.

The picture serves to remind us of all child victims, who nonetheless can sometimes turn their trauma and insecurity into glittering success, even if the price is high.

Elinor Kapp, Consultant Psychiatrist, Gwent Community Health NHS Trust, Child and Adolescent Mental Health Service, St Cadoc's Hospital, Lodge Road, Caerleon, Gwent NP6 1XQ

\section{Stage hypnosis: a personal account of the Kilroy Programme}

Tom Trevelyan, describes his impression of a debate for which he was considered too reasonable.

Stage hypnosis is as old as hypnosis itself. Mesmer would hypnotise groups of 200 and Mesmerism for entertainment was alive in the 1780s. Recently stage hypnotism has been undergoing a revival, particularly in Germany and England although it is banned in some Western countries including most states of the USA, Denmark and Israel.

There is a common format. Members of the audience are asked to lock their hands together by interlocking their fingers and then to pull them apart. Those who feel they cannot are invited on to the stage, often in groups, hypnotised rapidly and induced to undertake a number of 'entertaining' activities. These range from forgetting their wives' names or impersonating Mick Jagger, to explicitly sexual or absurd acts like copulating with chairs or impersonating washing machines.

The Campaign Against Hypnosis (CASH) invites representations from people who have suffered as a result of stage hypnosis. Largely as a result of their work the matter was raised in the House of Commons on 12 December 1994. An enquiry by Home Office officials was promised. The Kilroy Programme broadcast on this subject a week later.

I was invited to take part a day before the show as my name had been mentioned in association with a particular victim whom I was treating. I received early warning of the style of the programme. A young lady 